\title{
Clarifying Google Translate Problems Of Indonesia- English Translation Of Abstract Scientific Writing
}

\author{
S Suhono', M Zuniati ${ }^{2}$, W Pratiwi ${ }^{3}$, U A A Hasyim ${ }^{4}$ \\ English of Study Programme, Institut Agama Islam Ma'arif NU (IAIMNU) Metro, \\ Indonesia ${ }^{1,2,3,4}$ \\ \{suhono120708@gmail.com, pbi.tarbiyah.iaim@gmail.com², wiwiedpratiwi1987@gmail.com³, \\ alfaruqedu@gmail.com ${ }^{4}$ \}
}

\begin{abstract}
Infinite knowledge is jargon which refers to the development of science to make easier in doing anything, for instance, machine translation or trans tool. It is a popular program tool to provide translating text either Indonesia-English or English-Indonesia translation. Many kinds of machine translation, however, the most commonly accessed and easy used is Google translate as online tools. The researchers tried to clarify Google translate problem in measuring translation quality on Indonesia-English translation through Mona Baker's translation theory. The object of this research was an abstract of scientific writing. This research was qualitative research employing the descriptive method. The data collection technique of this research was selecting sentences, translating the sentences, and analyzing the sentences. The result showed that "Google Translate" had low quality and ineffective machine tools in translating Indonesia sentences into English sentences, with the highest probability of $16.2 \%$ which is only achieved when translating simple sentences of equivalence at the word level, grammatical equivalence and textual equivalent.
\end{abstract}

Keywords: Google Translate Problems, Abstract Scientific Writing, Cultural Relativity, IAIMNU. 


\section{Introduction}

Reproducing of written or spoken meaning, which transfer language in natural equivalent from language's source to target language (TL), named by translation. In translating, learners should study the grammatical pattern or structure sentences, the cultural context and situational communication of the source language (SL) text. Thus, the learner's language and error can be avoided. It is the way to reconstruct appropriate meaning from the source language to the target language without changing the purpose of the message sent.

Nowadays, many connections to technology's development to ease a lot of information, for instance, Google. It has functioned as a tool for finding specific or general information. These features, for instance, google translate, were the most magnificent tools. It was one of the products of Google which are introduced to the public in 2009. The managing of google translate, especially of different languages usage is magnificent changing from one language to another. It assists users from different kind countries, especially Indonesian learners.

Google translate has been growing to make it easier for the students to change their first language to foreign language, especially Indonesia-English Translation. Google translates like a machine system that responds to produce meaning to other meaning unaided scholar assistance. Now, it accrues a tool to be an intricate machine to translate. Recent research on translation, specifically in using machine translation is to be concerned by researchers. Researchers, for instance, Ghasemi and Hashemian suggested that machine translator or google translate gave a splendid service, an easy way to provide meaning in translating in specific changing's languages one to another. Approximately 90 languages are controlled by google translate, for instance at the level of lexical word, sentence, phrase or whatever other sources from website [1]. Moreover, it tally probability on the lexical word level, phrase be a correctable translation, consequently give rise to impact academic text of English translation results, either influence of students or students' text translation result.

Recently, another assessment had asserted by scholars. In an examination of the text, especially on subject-verb agreement, translation's result did not deal better with the subjectverb agreement aspect [2]. Next to other published journals online was found that using digital google translate, related academic purposes, had produced an error at the free text. It really needs a guide, since the hand-over impact of teaching in academic purposes [3].

Unfortunately, there are still many students used "Google Translate" as a tool to finish the assignment, for instance, abstract scientific writing as soon as possible. In this situation, many students use it without considering the result of translation's quality, "Google Translate" is their primary option machine translation to help their work in translating. It is because Google translate easily to be accessed despite don't know the obvious quality of Google translate's production. Hence, the researchers want to a deep understanding of translation quality of Google translate, especially Indonesian-English translation and to clarify the problems Google translates in Equivalence at the level word, grammatical Equivalence and Textual Equivalence in the level of sentence and compound sentence through Mona Baker's Translation Theory. Hence the researcher is interested to investigate it through this study by title: Clarifying Google Translate Problems of Indonesia-English Translation on Abstract of Scientific Writing 


\section{Theoretical Review}

\subsection{The Notion of Translation}

Learning the English language is one of science that should be learned to all the people [4], for instance, translation subject. In the communication process, automatically the people use language to transfer their ideas. Many ways are used to realize the goal, good communication, either spoken or written. One of the ways is a translation. The translation is the process by which the series of signifiers that constitutes the source-language text is replaced by a series of signifiers in the target language [5]. As Nida and Taber cited by [6] suggested that the process of translation focused on the meaning and style of the term in the reproduction of the receptor language in the closest natural proportional of the message's source language. It can be focused on reproducing the closest natural equivalent message from the source language to the receptor language (target language) both terms of meaning and style. They also involve cultural consideration it translating.

Recently, translation becomes an important thing in interpreting the meaning to transfer into a receiving device language. Translation also becomes the key to break through the information exchange. In education institutions such as schools or universities, translation is the first step to expose the brilliant idea from the Indonesian Language to English or vice versa. Translation becomes so important because translating produces transferring meaning into a receiving device in receptor language without replacing the meaning intended. The people translator uses their sense in the translating process. Not only translating word for word, but also translating contextually of the text.

Google Translate becomes so popular to translate many languages intended. The researchers have faith in producing an excellent translation is almost improbable but to execute a phenomenal translation is sensible. Google Translate can help a lot in translating simple sentences. But it is not reliable because in semantic aspects, when translating the source text, there was a specific one, for instance, some lexical that producing translation not precise and not translated Indonesia into the English language [7]. Nevertheless, another researcher assumes about strong opinion related to the capability of machine translation. He asserted that machine translation, that frequently used by people is sometimes tricky and challenging [8]. It was the real phenomenon that the quality of Google translate was to be the dispute's argument.

\subsection{Effective Translation}

There are many theories that can be used to help translate effectively. Baker in her book thinks that an effective translation is a translation that fulfills the parameters that she mentioned in her book. The parameters consist of 4 criteria, which are already in hierarchical order. According to Baker, the organization of these criteria is founded on a principle translation, beginning in around the simplest possible rating and then accrue into complexity by widening its focus on each criterion. The criteria of translation, for instance, the parity level of the word, the parity above word level, grammatical parity, textual parity [9]. 


\subsection{Methods of Translation}

The term method derived from the word method in English. In Macquarie Dictionary, a method is a way of doing something, especially in accordance with a definite plan. There are some kinds of method of translation, classified into seven categories, for instance, word- forword-translation, literal translation, faithful translation, semantic translation, Adaption, free translation, idiomatic translation, and communicative translation [10].

Based on the description above about the methods of translation, it can be inferred that semantics and communicative translation fulfill the purpose of the translation. Actually, a semantics translation is written at the author's linguistics level, a communicative at the readerships. Otherwise, a good translation method, which are entangled with communicating the meaning of the (S) source language using the natural grammatical and lexical items of the receptor language, is an idiomatic translation.

\subsection{The Concept of Meaning Indonesia-English and English Indonesia Translation}

Meaning, which is related to the language function's communication, is closely associated with context, situation, grammatical, society culture to where the meaning occurs. There were different kinds of meaning in the translation category, for instance, lexical meaning and structural or grammatical meaning, textual meaning, and contextual or situational meaning.

Lexical meaning in translation, which happens when the word used not in context or without any correlation to another word, becomes problematic transferring meaning SL to TL. The researchers found some of the lexical's problems in processing translating.

In English, the word "rice" has a lot of equivalent in Bahasa Indonesia, for instance, "gabah", "nasi", "beras". The interpreter should examine and analyze related to context or situational to decide the appropriate meaning in receptor language besides. If there is another alternative sentence, he would not discover any complications. Furthermore, Polysemy and Homonym are a word, which that on meaning too. These can be a problematic translation. For instance:

The word "fresh" in the phrase "fresh air" has the meaning in Indonesia "segar". The word "fresh breeze" has the meaning in Indonesia "angin sejuk". However, in slang language "fresh" in "fresh boy" means "kurang ajar".

Grammatical or Structural meaning created form word order i a phrase through wordformation or in a sentence. If a receiving device language and the source language are similar, it is easier for the translator to translate the text receptor language into source language in the context of structure. However, if the receptor language and source languages are different in the context of structure or grammar, the translator will find difficulty in adjusting or adapting the grammar. From the researchers' experiences, the language in one family has a similar characteristic in grammar and language which come from different family have a different characteristic of grammar. It can be assumed that translation from English to Indonesia and vice versa will find a problem in adjusting or adapting English and Indonesia, for instance, translating Indonesia to English sentences;

"Dia (laki laki) membersihkan lantainya setiap hari"

"He cleans his floor every day"

"Dia (laki laki) sedang membersihkan lantainya" 
"He is cleaning his floor"

"Dia (laki laki) sedang membersihkan lantainya"

"Dia (laki laki) telah membersihkan lantainya"

"He had cleaned his floor

From the examples above, it has different formation or orders or words, resulting in different meanings. Example 1 described the habit activity (every day), Example 2 described now, and Example 3 described the last event.

A meaning, which is resolved by its relationship with another word in a sentence, is characters of textual meaning. Like the word of "hand" in English, in Indonesia language has the meaning "tangan", unfortunately, it has several meaning, for instance:

"Novel ini buah "tangan" seorang penyair Indonesia"

"Uluran "tangan" para relawan Indonesia telah memberikan dampak yang signifikan untuk para korban bencana alam"

"Mahasiswa IAIMNU menjadi "tangan" kanan ketua program studi bahasa inggris"

Meaning form, which is emerged from a contextual action and situational action where the phrase sentences is used, is characteristic from contextual or Situational meaning, for instance :

"a lecturer, which do the mistake in her jobs, is always slothful every meeting. Her dean always admonishes but she keeps protection her arguing. This situation makes dean's annoyance. In the end, he said: "it was enough. Good morning"!

The instructions in saying: good morning which is spoken in loud voice intonation is has not meant greeting unfortunately it is a code to command the lecturer to go out of the class as quickly as possible. There isn't any graciousness message anywhere in the salutation. Therefore, the intended meaning of the idiomatic translation in Bahasa Indonesia is "cukup keluar"

\section{Research Method}

The researchers used qualitative study because the aim of this study is to know the accuracy of Table to translate Indonesian into English sentences effectively, which has given a new understanding of the subject. The source data are abstract of scientific writing at IAIMNU Metro Lampung. The researchers had analyzed types of sentences. Those were a simple sentence, compound sentence, and complex sentence In this investigation the researchers only used five parameters from the parameter explained. In data analyzed, the researchers used Baker's Theory parameters in the translation field that is: Equivalence at Word Level, Grammatical Equivalence, and Textual Equivalence Furthermore, using evaluation in each sentence which is translated by "Google Translate". 


\section{Finding And Discussion}

\subsection{Simple Sentence}

(Equivalence at Word Level)

Then the researchers found some mistakes in simple sentences of Equivalence of word level.

1) Indonesia Language:

"Penelitian ini bertujuan untuk menemukan dan mendeskripsikan permasalahan pembelajaran dalam penggunaan metode yang ada di sekolah"

English Language:

This study aims to find and describe the problem of learning in the use of method that exist in schools"

The word sekolah was translated to schools. The word sekolah was a singular word while "schools" was a plural word.

2) Indonesia Language:

"Dalam pelaksanaan pembelajara mereka harus memberikan kesempatan untuk bertanya"

English Language:

"In the implementation of learning, they should provide an opportunity to ask questions"

The next mistake was that there was a word translated incorrectly; harus. The word harus should be translated as "must" instead of "should" since the word harus in this sentence had the meaning of "intended to" not as an suggestion or advice. That was why the word had to be translated as "must". The second

The word bertanya was translated to questions. The word bertanya was a singular word while "questions" was a plural word.

3) Indonesia Language:

"Pengaplikasian mata pelajaran Aswaja memiliki peluang untuk pemahaman keagamaan yang moderat dan terindar dari radikalisasi"

English Language:

"The application of Aswaja subjects has an opportunity for moderate religious understanding and escapes from radicalization" 
The mistake was the word mata pelajaran which was a singular word translated as "subject" which was a plural word; furthermore, the translation result did not indicate that the word "subjects" was a singular word. To make the translation result indicates that the word was a singular word the word could be translated as "subject".

4) Indonesia Language:

"Kemudian Penelitian ini dilaksankan di pondok pesantren Pondok"

English Language:

Then the research was conducted in boarding schools". The lexical word pondok pesantren was translated to schools. The word pondok pesantren was a singular word while "schools" was a plural word.

5) Indonesia Language:

"Peneliti telah mempresentasikan hasil penelitiannya"

English Language:

"Researchers have presented the results of research"

The word Peneliti indicates singular subjek, unfortunately the result of google translate showed plural subject form researchers. The translation result should be "researcher".

\subsection{Simple Sentence}

(Grammatical Equivalence)

1) Indonesia Language:

"Pendidikan agama Islam di sekolah secara substantif memiliki peran yang sangat penting.

English Language:

"Religious education in schools substantively Islam has a very important role."

The word "substantively" cleaves the phrase, which explained in the equivalent above word became "Islamic education religious", that caused the translation grammatically strange. "Substantively" should be before the verb since this sentence was with no auxiliaries. Thus, the best translation is "Islam religion education in schools substantively had a very important role.

2) Indonesia Language:

"Pesantren - Pesantren menganggap bahwa Indoensia merupakan sudah sesuai dengan Ideologi Negara.

English Language:

"Pesantren - Pesantren considers that Indonesia is in accordance with the Stat Ideology" 
The mistake found in this sentence was the main verb "considers" presented in singular form while the subject is plural pesantren - pesantren. So, the letter "s" should be omit to indicate a singular form on a verb, it should be put "consider".

3) Indonesia Language:

"Tujuan dari penelitian ini adalah untuk menemukan dan menelaah Pendidikan yang terintegrasi di Era Milenial, khususnya pada mata pelajaran Pendidikan Agama Islam di IAIM NU Metro Lampung”"

\section{English Language:}

"The purpose of this research is to discover and examine the integrated Education in the Millennium Era, especially on the subject of Islamic Religious Education at IAIM NU Metro Lampung"

The word "....to discover and examine..." should be parallel sentence in to-infinitive (to + Verb1). This sentence should be " to discover and to examine..."

\subsection{Simple Sentence}

\section{(Textual Equivalence)}

1) English Language:

“Agama Islam yakni sebagai agama rahmatan li "l- ,ālamīn, tanpa kekerasan, cinta perdamaian, dan mengedepankan cinta kasih"

Indoneisa Language:

"Religion of Islam as a religion of liberation li "l-" ālamīn, non-violence, love of peace, and promote love"

The mistake of Indonesia-English translation occurred in word of "promote". The result of the translation of mengedepankan is "promote". "promote" is "to encourage the popularity, sale, development or existence of something" or "to raise someone to a higher or more important position or rank. That was not in line with the meaning sense of word mengedepankan which actually want to consider "love" as the most important thing in life. Therefore, the more appropriate meaning for "promote" is "prioritize" than "promote".

2) Indonesia Language:

"Tujuan dari penelitian ini adalah untuk menemukan dan menelaah Pendidikan yang terintegrasi di Era Milenial, khususnya pada mata pelajaran Pendidikan Agama Islam di IAIM NU Metro Lampung”

English Language: 
"The purpose of this research is to discover and examine the integrated Education in the Millennium Era, especially on the subject of Islamic Religious Education at IAIM NU Metro Lampung"

The word "menemukan" was inappropriate translated to "discover". Because the meaning of "discover" is "to find information, a place or an object, especially for the first time intuitively"96, while mencari here is inclining to achieving something by some action in searching. So, the word "find" is more appropriate to be used in this translation than the word "discover".

3) Indonesia Language:

"Kegiatan orang desa ini dilakukan pada legi dan wage"

English Language:

"The activities of the villagers are done on legi and wage"

4) Indonesia Language:

"kegiatan telon-telon dan piton-piton orang jawa merupakan kegiatan rutin"

English Language:

"The activities of telon-telon and python of Java people is a routine activity

The underlined words above, "legi" “wage”, “telon-telon”, "piton-pitonan were untranslated words into Indonesia language. In this case, google translate could not change the Source language into the target language appropriately. Hence, cultural relatively which is proposed by Kadarisman, that is referred to items that are culture-specific and linguistic relatively is determined by cultural relatively. Furthermore, the language was determined by culture and thought patterns [11]. It could not be applied in machine google translate. To overcome those problems, the translators (people) do lexical borrowing preference in order to be understood by the readers. The word "legi" and "wage" can be understood as dino pasaran or pasaran days, which refers to the daily activity of the transaction of the people in the marketplace. Furthermore, the words "telon-telon" and "piton-piton" were untranslatable in derivation words.

Based on the phenomena above, especially related to culture, lexical equivalents either Indonesia to English or English to Indonesia are very essential to determine the appropriate meaning in the target language (TL).

\subsection{Compound Sentence}

(Equivalence at Level of the word)

1) Indonesia Language:

"Kejadian tersebut bisa saja salah dalam kasus kasus tertentu, akan tetapi tidak bisa digeneralisasi 


\section{English Language:}

"The incident may be wrong in a particular case, but it can not be generalized"

The mistake was the word kasus kasus which indicate plural form translated as "case" which was a singular form. Afterward, the result of translation did not indicate that the word "case" was a plural form. In this case, to indicate the translation result was plural form, it could be translated as " in particular cases".

\subsection{Compound Sentence}

(Grammatical Equivalence)

1) Indonesia Translation:

"Pada era globalisasi, pemuda adalah tulang punggung negara sebagai penggerak persatuan dan kesatuan bangsa"

English Translation:

"In the era of globalization, youth is the backbone of the state as driver of unity and national unity"

The word "youth" in this sentence has the meaning "young people, both male and female, whether as a person or a group".

The word "youth" here was an uncountable noun. Based on the explanation, to be "is" should be changed to be "are".

The researchers found many mistakes which are done by "Google Translate". Some types of sentences translated ineffectively and the success rate was close to zero percent. Bellow was the table of translation success rate:

Table 1. The translation Success rate of Google Translate

\begin{tabular}{|l|c|c|c|}
\hline $\begin{array}{c}\text { Sentence } \\
\text { Types }\end{array}$ & $\begin{array}{c}\boldsymbol{\Sigma} \\
\text { Sentence }\end{array}$ & $\begin{array}{c}\boldsymbol{\Sigma} \\
\text { correctly } \\
\text { Translate } \\
\mathbf{d}\end{array}$ & Rate \\
\hline $\begin{array}{l}\text { Simple } \\
\text { Sentence }\end{array}$ & 31 & 5 & $16.2 \%$ \\
$\begin{array}{l}\text { Compound } \\
\text { Sentence }\end{array}$ & 19 & 4 & $21 \%$ \\
\hline
\end{tabular}

"Google Translate" in each parameter that is used for analyzing the sentences; they are as follows: 
1) Equivalence at Word Level

a. Translating Plural word into a singular word

There are many causes of the plural word, which is supposedly translated as a plural word, which is translated as a singular word.

b. The translation result has different meaning after translation

This is the most basic form of the mistake in translation. If the translated word has a different meaning from the original sentence, the information which should be delivered will be wrong.

c. Inconsistency of translation result

The word which should be translated is not translated in the translation result. The word still exists in the translation result, but it retained its original form. There is an exception where the word cannot be translated, but it mostly occurs on a proper noun

2) Equivalence at Word Level

a. Using word for word translation

Phrases and clauses should be translated as a phrase and clause, not as a set of the word. Translating phrases or clauses by word per word translation would cause the phrase or clause has a strange meaning in the translation result.

b. Random word order

Random translation result in a phrase is not only when a phrase translated into word per word translation but also the function and the structure is weird.

c. Agreement the word order in a phrase

The structure of some words connected to others whether after or before the word has the role. It is called an agreement. Every word in a sentence does not stand by itself but it should consider the function or the form of other words building a complete sentence.

3) Grammatical Equivalence

a. Problem of verb

A complete sentence or clause is when it has the main subject and the main verb. The verb in a sentence is not the only verb as its form but also as its function. Afterward, it can not be called as a sentence when it does not have. Furthermore, it happens in whether a passive sentence, active 
sentence or even getting added-word at the verb. The sentence will be not only an uncomplete sentence but also change the meaning intended to convey

b. Random word order

A random translation result in the grammar part is not only when a clause or sentence translated into word per word translation but also the function and the structure in the clause or sentence is weird

c. Agreement on each phrase and clause

The structure of some words connected to others whether after or before the word has the role. It is called an agreement. Every word in a sentence does not stand by itself but it should consider the function or the form of other word building a complete sentence

d. Unable to identify singular and plural verb

Grammatically, every verb in a sentence or clause has to agree with the subject. When the subject is a singular noun or noun phrase, the verb must be also in a singular form. Yet, the sentence or clause is incorrectly translated since it does not happen

e. Wrong word order

A wrong word order is when a word is translated not in its original function. Then, it takes the form of the word not as the proper form

\section{4) Textual Equivalence}

Summing up the results, it can be concluded that the quality of "Google Translate" in translating Indonesia sentences to English sentences is low. The highest percentage of the correct translation of students at simple sentences only $(16.2 \%)$ or 5 from 31 sentences. The mistakes found in the translation result mostly are equivalent at the word level. Furthermore, cultural relatively in machine google translate could not be applied, for instance in the word "legi", "wage", "telon-telon", "piton-piton" etc..

\section{Conclusion}

Summing up the results, it can be concluded that the quality of "Google Translate" in translating Indonesia sentences to English sentences is low. The highest percentage of the correct translation of students at simple sentences only $(16.2 \%)$ or 5 from 31 sentences. The 
mistakes found in the translation result mostly are equivalent at the word level. Furthermore, cultural relatively in machine google translate could not be applied, for instance in the word "legi", "wage", "telon-telon", "piton-piton" etc.

\section{References}

[1] H. Ghasemi and M. Hashemian, "A Comparative Study of Google Translate Translations: An Error Analysis of English-to-Persian and Persian-to-English Translations," English Lang. Teach., vol. 9, no. 3, p. 13, Jan. 2016.

[2] M. Bozorgian and N. Azadmanesh, "A survey on the subject-verb agreement in Google machine translation,” Int. J. Res. Stud. Educ. Technol., vol. 4, no. 1, 2015.

[3] M. Groves and K. Mundt, "Friend or foe? Google Translate in language for academic purposes," English Specif. Purp., vol. 37, pp. 112-121, 2015.

[4] S. Suhono, "Surface Strategy Taxonomy On The Efl Students Composition A Study Of Error Analysis," J. Iqra' Kaji. Ilmu Pendidik., vol. 1, no. 2, pp. 1-30, 2016.

[5] L. Venuti, The translator's invisibility: a history of translation. London; New York: Routledge, 1995.

[6] Choliludin, The technique of making idiomatic translation. Jakarta: Kesaint Blanc, 2005.

[7] F. H. Amanah, "Errors Made By Google Translate and Its Rectification By Human Translators Faculty of Languages and Linguistics," University of Malaya, 2017.

[8] H. Zheng, "A case study of machine translation: Problems and suggestions," Int. J. English Linguist., vol. 5, no. 2, p. 92, 2015.

[9] M. Baker, "Mona Baker. In Other Words. A coursebook on translation.," Target, vol. 24, no. 1, pp. 191-193, Sep. 2012.

[10] P. Newmark, A textbook of translation. Prentice Hall New York, 1988.

[11] A. E. Kadarisman, "Linguistic relativity, cultural relativity, and foreign language teaching," TEFLIN J., vol. 16, no. 1, pp. 1-25, 2015. 